\title{
An Archetypal Analysis For The Development Of A Generalized Decision- Making Model In Groups As A Prerequisite For Productive Government And Leadership
}

George S. Spais, (e-mail: gspais@cc.uoi.gr), University of Ioannina, Greece Stavros M. Theofanides, (e-mail: stheofan @ panteion.gr), Panteion University of Social \& Political Sciences, Greece

\begin{abstract}
The original cultural roots of Economics, Informatics and Decision Sciences are related to its genesis, mythology, and prehistory and, of course, to its proto-foundations as a scientific discipline. The knowledge of the cultural roots of the Economics and Decision Sciences will promote our understanding of this vital topic and will deepen our thinking about its importance and usefulness, both as a practical and theoretical ergon/engagement discipline. Under this prism, the present work is examining the contributory role of god Hermes to the effectiveness and efficiency of the "Olympian Style of Management" in the ancient Greek society. So, the major objective of this work is to propose an integrated model for productive (= effective + efficient) decision-making in groups. Group decision-making is the process of arriving at a judgment based upon the feedback of multiple individuals. Such decision-making is a key component to the functioning of an organization, because organizational performance involves more than just individual action. Due to the importance of the group decision-making process, decision-making models can be used to establish a systematic means of developing effective group decision-making. In our study, we have examined twenty-two (22) ancient Greek works. Our intention is to understand god Hermes' personality traits and activities, as an indicator of the level of knowledge of Ancient Greeks on management science and their perceptions on the value of information and knowledge management in a group decisionmaking process. The authors propose that rational decision-making in all levels, in both government and entrepreneurship; prerequisites high quality of data, integrated information, convergence and consistency. The major implication of this study is related to the raising challenge for the next years, where academics must promote the systemic, multidisciplinary way of thinking to business students from economics, management and informatics fields.
\end{abstract}

\section{INTRODUCTION}

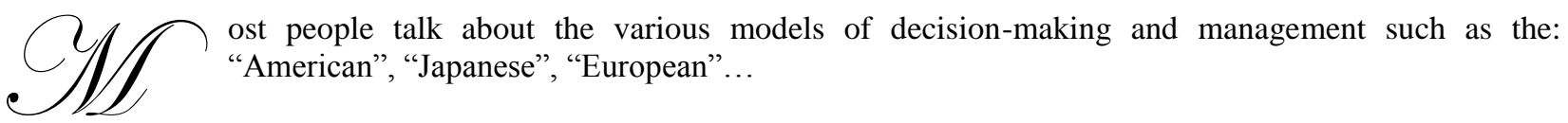

Modern technology and psychology have attempted to tame the great decision dilemma in the 20th century. Application of the scientific method in the area of psychology has led to major revelations about how people make decisions, pointing out typical flaws in our interpretation of data that influences our choices, and quantitative techniques to give value to what we feel. In modern management science literature a plethora of decision-making theories and methods are presented, such as: a) games' theory and economic behavior, b) bounded by satisfying limits, c) fuzzy decision-making theory, d) lateral thinking, e) optimization of power decisions, f) count down (bayesian style) and g) trade-off techniques to prioritize criteria. 
However, the first model of management and decision-making in the pre-history as referred to in Homer's works ("Odyssey" and "Ilias") seems to be the Olympian style (Theofanides 1999). The frequent presentation of this style of management and decision-making in other ancient writers like Hesiod, Herodotus, Plato, Aeschylus and others makes it extremely interesting since this was the original method of managing needs-problems-issues in antiquity.

In Greek mythology, as developed circa 10.000-5.000 B.C. there is a clearly defined mythical world, that is, the Olympian System of six gods and six goddesses (the 12 Olympian Gods) headed by the co-sovereigns Zeus and Hera. The council of gods headed by Zeus managed all world affairs following the original Olympian Style of management (decision-making in groups/"groupies").

Although there is no science of myth to explain mythology in empirical terms, it is certain that Greek mythology refers to an imaginary world, which brings a close resemblance to many aspects of our modern world.

The basic elements of this style of management are that it defines the best solution ("the wise solution") based on dialogue with all parties concerned using Hermes' reliable data and power to implement the wise decisions (see Zeus' thunderbolts).

\subsection{Archetypal References Based on Greek Mythology \& their Contribution to Modern Business Literature}

The cultural roots of Economics, Management Science, Informatics and Marketing are related to its genesis, mythology, and prehistory and of course, to its proto-foundations as a scientific discipline. The World Book Encyclopedia says: "we study mythology because it is the religion of a primitive people. And it is their science and literature as well. It is their religion because it tells what the gods do and what the people should do to please the gods. It is their science because it explains natural events by making up supernatural causes for them." (1955 edition, Vol.11, p.5375). Unfortunately, economists and management scientists know very little or nothing about the cultural roots of our discipline, despite the fact that Economics is indeed the most vital activity of all other human activities. The analysis of archetypes it seems to be a quite unknown field for the majority of the academics from the different fields of Economics and Business Administration. This gap raises issues about the need not only to deepen our historical knowledge but also to empower our knowledge by analyzing archetype symbols, as sources of hidden knowledge. The knowledge of the cultural roots of Economics and Management Science will promote our understanding of this vital topic and will deepen our thinking about its importance and usefulness, both as a practical and theoretical ergon/engagement discipline.

There are many interesting examples on the analysis of archetypes, from many academics from the fields of Social Sciences, in order to review and propose new theories. "Gods in Every Man" (Harper and Row, 1989) and "Goddesses in Every Woman" (Harper and Row, 1984) by psychotherapist Jean Shinoda Bolen used an overlay of Greek and other mythic types to organize the variations in human behaviors into sixteen types, eight female, eight male. These cultural images of various human archetypes can further understanding of clusters of tendencies and possibilities for future growth and development, particular as the characters' mythic stories are learned, their strengths and weaknesses studied.

They include, for men:

- $\quad$ Zeus, God of the Sky, Realm of Will and Power

- $\quad$ Poseidon, God of the Sea—Realm of Emotion and Instinct

- $\quad$ Hades, God of the Underworld - Realm of Souls and the Unconscious

- Apollo, God of the Sun-rcher, Lawgiver, Favorite Son

- Hermes, Messenger of God and Guide of Souls - Communicator, and Traveler

- $\quad$ Ares, God of War-Warrior, Dancer, Lover

- $\quad$ Hephaestus, God of the Forge - Craftsman, Inventor, Loner, and

- Dionsyius, God of Wine and Ecstasy—Mystic, Lover, Wanderer. 
The female mythic types are:

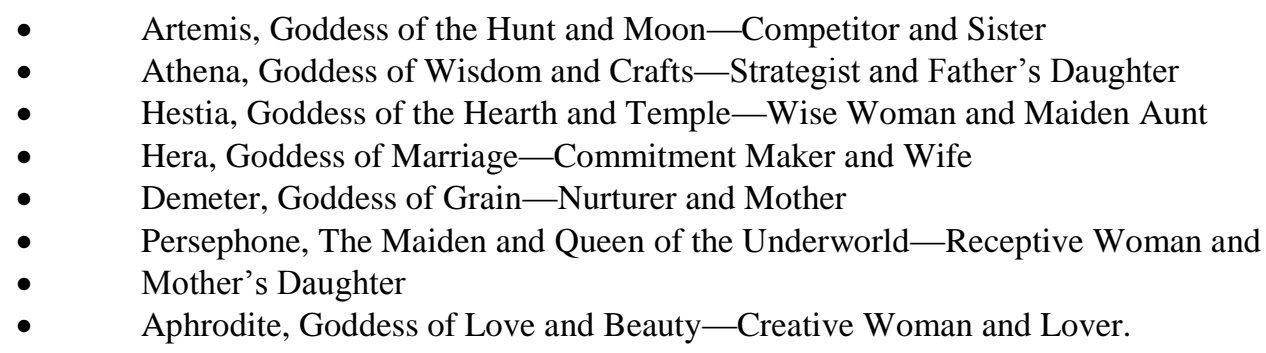

\subsection{Background Study}

It is interesting and pedagogical to compare the Olympian Style of management to those existing main styles: the "American" and the "Japanese".

A. The American Style of management is based on the following three "soft S's": Strategy, Structure and System.

The emphasis on those three basic aspects of management is a rather orthodox and synoptic view of the American Style of management, which in view of its positive results in many fields of the American giant corporations seems to be successful.

However, taking some isolated criteria of success, such as growth performance, competitiveness and market share gains, it seems that the American Style of management is not extremely dynamic.

B. The Japanese Style of management, on the other hand, is based on the following four "hard S's": Staff, Skills, Style and subordinate goals (shared values).

On the basis of the performance of the Japanese Style of management with the accepted criteria of evaluation, it is recorded that this style of management seems to be more successful that the American in some sectors. The emphasis on staff and skills produces more positive results, especially in the fields of productivity gains and increased shares in the world markets.

C. The comparative advantage of the Olympian Style of management seems to be the following:

- It is problem-oriented rather than directed to stated objectives.

- It gives emphasis on collecting and evaluating all relevant data through the full capacity of Hermes (the God of Informatics).

- It is extremely participatory since all decision are taken with the contribution of all Gods, in an interdisciplinary approach.

- It is dialectical since decisions are based on an extended dialogue.

- It uses power to implement wise decisions.

Based on the concept of Olympian Style of Decision Making, as introduced by Theofanides (1999), a generalized model for decision-making in private and public organizations was presented in the book: A Manual for Effective Management of Public Affairs (1989).

The theoretical basis of this work is derived from the generalized model for decision-making in private and public organizations (Theofanides 1989). 


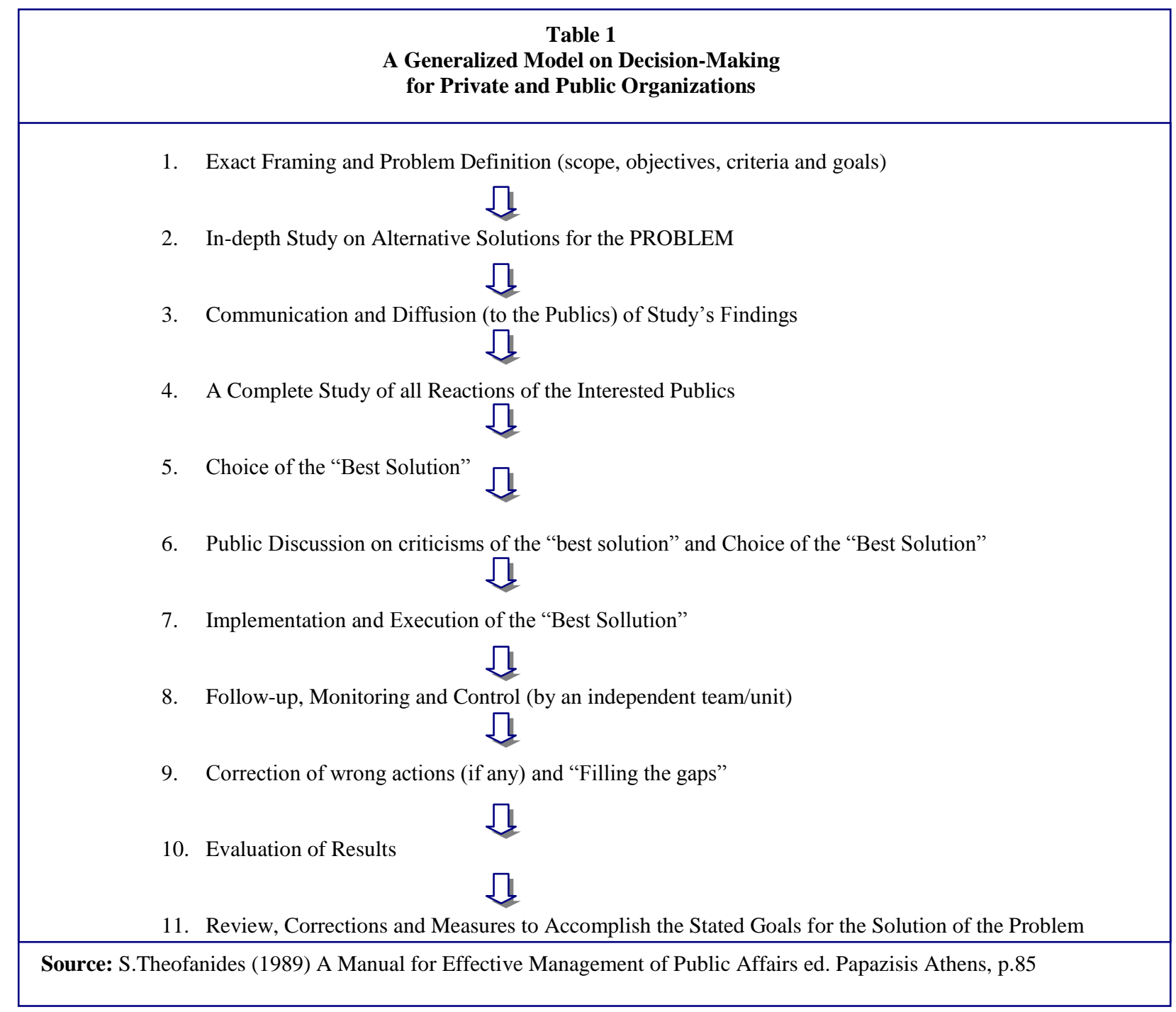

But what was the role of god Hermes in the Olympian Style of decision-making? According to modern literature, "good" or productive leadership seems to be expressed from the known formula of management science referred to the productivity of management/leadership efforts: effectiveness (degree of achieving goals) to efficiency (degree of exploitation of the entered information). This means that variables that impact to higher levels of efficiency impacts directly to the productivity of the leadership efforts (through the higher degree of achieving goals).

Taking into serious consideration that Greece it was one of the leading societies in antiquity with great leaders; we believe that there is research question that modern scholars of management science must not ignore. Why ancient Greeks have adopted the Olympian Style of Decision Making? (a decision-making model in groups, which has been developed by God Zeus).

Based on the above, the present work aims to understand the true role of god Hermes (the god of communication and informatics, which seems to play a protagonistic role in this model). Such an approach will allow us to understand and outline the issues that make the Olympian style of decision making, as the only model that can lead to productive government and leadership. 
In terms of the above research scope, we have examined twenty-two (22) ancient Greek works. Our intention is to understand god Hermes' attributes (by decoding symbols) as an indicator of the level of ancient Greeks' knowledge and their perceptions on the value of information and knowledge management in a decision-making process, in terms of productive leadership.

The cases related to the duties of god Hermes are studied under the prism of the characteristics of the "mathematically" engineered "Olympian Management System", as presented above.

\subsubsection{Information Management and Knowledge Management: The raising issue of data quality (the cooperation between god Hermes and god Apollo)}

Evidently, the expandable nature of information clearly raises issues of information management. The expandable properties of information mean that it is simultaneously burdensome while liberating. "Information overload" bears testimony to this. The twenty-first century has ushered in an era of "information saturation", where the existence of Google functions as a "calming tonic" against the infinitely expanding information chaos exemplified by the web (Wallis 2003). Instead, the limits to expansion are governed by the time that minds have to absorb and analyze this information. Though information overload has always presented problems for management, the past decade has witnessed an information explosion and a further rise in the phenomenon (Boyd 2004). This rise is partly attributable to a lag in the effective and efficient means by which to manage this information. Unfortunately, this overload often compels users to oversimplify what is before them thus discarding and ignoring altogether pertinent and wholly valuable information. The function of information management is to facilitate a means whereby expandability is checked and to ensure that only information pertinent to the desired use is delivered.

Management in this respect may entail compression, which causes its own dilemmas. The compressibility of information has positive connotations for easy management and facilitates information retrieval and simpler user research. Yet, though information is in many cases inherently compressible, most instances necessitate that it be distilled, in order to be compressed (Cleveland 1982). This presents information managers with a perplexing conundrum as some information is destined to go missing through compression. What is lost may be deemed valuable or it may be deemed insignificant; the distinction is largely context dependent and is hence entirely subjective.

Though entirely context dependent, it is clear that with information resides some sort of value. As we have seen, value underpins traditional resources and is inextricably related to the scarcity and output of these resources. As the value of information as a resource becomes paramount in our new economy, so does our need to evaluate it. The value of information is directly correlated to its utility, which is, and will always be, determined by its context. The emerging conundrum for the information manager - or those staff spearheading the modern and industrial adjunct of information management, "knowledge management" - is therefore to recognise these difficulties and to apply appropriate criteria for determining the value of information within these contexts and to expedite a knowledge sharing environment, as demonstrated by various scholars such as: Bogdanowicz and Bailey (2002), Burstein and Linger (2003), Squier and Snyman (2004). As Oppenheim et (2000, p.56) note:"... every organisation has data in some format, but identifying what data if any has value or indeed potential value creates difficulties".

In mythological antiquity, Hermes was the god of Economics, Culture and Informatics -the messenger of Olympian gods responsible for collecting data and information for their decision-making. He co-operated closely with his brother, Apollo, the god of light and the founder of the First Central Intelligence Institute and a Systematic Cyber Data-Bank, (see Apollo temple in Delphi and the Delphic Oracle model) to exchange information on mount Olympus for rational choice according to the Olympian style of management and administration. According to the historians, Fantenrose (1978), Parke and Wormell (1956), the interaction and cooperation of all the sections of the temple of Apollo (operating as an interdisciplinary think-tank of approximately 90-100 priests, the most well-educated experts of antiquity) established a unique center for producing "responses" in the form of advise, forecasts, guidance and proverbs. According to Fantenrose (1978), Parke and Wormell (1956) the success this information processing public institution was based on thousand years recorded history. 


\section{RESEARCH METHOD}

The original cultural roots of Economics and Decision Sciences are related to its genesis, mythology, and prehistory and, of course, to its proto-foundations as a scientific discipline. The knowledge of the cultural roots of the Economics and Decision Sciences will promote our understanding of this vital topic and will deepen our thinking about its importance and usefulness, both as a practical and theoretical ergon/engagement. Under this prism, this study is examining the case of the ancient Greek god Hermes from the Greek mythology by studying the works of Hesiod and Homer. For most people the term "myth" denotes stories that are not really true that have been made up and passed down by races or nations of people to explain their origins or the origin of the world and man and the problems and basic principles of life and religion.

Webster's Third New International Dictionary defines "myth" as: "a story that is usually of unknown origin and at least partially traditional, that ostensibly relates historical events usually of such character as to serve to explain some practice, belief, institution, or natural phenomenon, and that is especially associated with religious rites and beliefs."

The World Book Encyclopedia says: "we study mythology because it is the religion of a primitive people. And it is their science and literature as well. It is their religion because it tells what the gods do and what the people should do to please the gods. It is their science because it explains natural events by making up supernatural causes for them." (1955 edition, Vol.11, p.5375).

Although little can be done to combat challenges concerning the generalizability of case studies, "most writers suggest that qualitative research should be judged as credible and confirmable as opposed to valid and reliable" (Merriam 1985). Likewise, it has been argued that "rather than transplanting statistical, quantitative notions of generalizability and thus finding qualitative research inadequate, it makes more sense to develop an understanding of generalization that is congruent with the basic characteristics of qualitative inquiry" (1985). After all, criticizing the case study method for being ungeneralizable is comparable to criticizing a washing machine for not being able to tell the correct time. In other words, it is unjust to criticize a method for not being able to do something, which it was never originally designed to do in the first place.

For our study we have considered Merriam's suggestions (1985) on how case study researchers might actively combat the popular attacks on the validity and reliability of case studies.

Data gathering on web sites helped us to insure the accuracy of the findings by providing the researcher with more concrete information upon which to formulate interpretations.

Additionally, collection of referential materials was quite valuable for the document support. For example, Emig (1971) supports her initial propositions with historical accounts by writers such as T.S. Eliot, James Joyce, and D.H. Lawrence. Emig also cites examples of theoretical research done with regards to the creative process, as well as examples of empirical research dealing with the writing of adolescents.

\section{ABOUT THE ANCIENT GREEK WORKS ON GOD HERMES}

\subsection{About the Works of Hesiod and Homer: The two most important writers for modern historians}

Most people when they hear the term "myth" think of Greek mythology. Many of the names and ideas of Greek mythology have found their way into our language and literature, including our calendar and the names of the planets.

The World Book Encyclopedia says: "the basic sources for classical Greek mythology are Hesiod's Theogony and Homer's Iliad and Odyssey, which date from about the 700's B.C....[These works] contain most of the basic characters and themes of Greek mythology." 
Hesiod lived in the 8th century BCE, probably about the same time or shortly after Homer. He refers to himself as a farmer in Boeotia, a region of central Greece, but other than that we know little. His poetry codified the chronology and genealogy of the Greek myths. Works and Days and the Theogony are the only two complete works we have of Hesiod, other than the first few lines of a poem called the Shield of Heracles.

In Works and Days Hesiod divided time into five ages:--the Golden age, ruled by Cronos, when people lived extremely long lives 'without sorrow of heart'; the Silver age, ruled by Zeus; the Bronze age, an epoch of war; the Heroic age, the time of the Trojan war; and lastly the Iron age, the corrupt present. This is similar to Hindu and Buddhist concepts of the Kali Yuga. The idea of a Golden Age has likewise had a profound impact on western thought. Works and Days also discusses pagan ethics, extols hard work, and lists lucky and unlucky days of the month for various activities.

The Theogony presents the descent of the gods, and, along with the works of Homer, is one of the key source documents for Greek mythology; it is the Genesis of Greek mythology. It gives the clearest presentation of the Greek pagan creation myth, starting with the creatrix goddesses Chaos and Earth, from whom descended all the gods and men; it mentions hundreds of individual gods, goddesses, demi-gods, elementals and heroes.

\subsection{God Hermes in Homer's Works}

Table 1

God Hermes in Iliad and Odyssey listed by book and line

\begin{tabular}{|c|c|}
\hline $\begin{array}{c}\text { WORK 1: } \\
\text { Hermes in the Iliad } \\
\text { (listed by book and line) }\end{array}$ & $\begin{array}{c}\text { WORK 2: } \\
\text { Hermes in the Odyssey } \\
\text { (listed by book and line) }\end{array}$ \\
\hline $\begin{array}{l}\text { - } 02.103 \text {...At an assembly of the Akhaians } \\
\text { (Achaeans), Agamemnon held up a scepter made by } \\
\text { Hephaistos (Hephaestus) which was given to Zeus, } \\
\text { then to Argeiphontes (Hermes), then to Pelops, then } \\
\text { to Atreus and finally to Agamemnon } \\
\text { - } \quad 05.390 \text {...Dione explains to the wounded } \\
\text { Aphrodite that the other Immortals had endured } \\
\text { hardship too; she told Aphrodite of the time Hermes } \\
\text { had to free Ares from Ephialtes and Otos (Otus) } \\
\text { - } 14.491 \text {...The Trojan, Ilioneus, was loved by } \\
\text { Hermes but was killed horribly by Peneleos } \\
\text { - } 15.214 \text {...When Iris delivers Zeus' message to } \\
\text { Poseidon, he declares that he will leave the } \\
\text { battlefield only if he, Athene (Athena), Hera, } \\
\text { Hermes and Hephaistos (Hephaestus) are eventually } \\
\text { allowed to storm the walls of Troy } \\
\text { - } 16.181 \text {...Hermes fell in love with Polymele when } \\
\text { he saw her dancing in the choir of clamorous } \\
\text { Artemis } \\
16.184 \text {...Hermes, the healer, and the maiden, } \\
\text { Polymele, had a son named Eudoros (Eudorus) } \\
\text { - } 20.037 \text {...Hephaistos (Hephaestus), Hera, Athene } \\
\text { (Athena), Poseidon and Hermes descend Mount } \\
\text { Olympos (Olympus) to join the Akhaians } \\
\text { (Achaeans) on the battlefield } \\
\text { - } 20.072 \text {...Leto faces Hermes on the battlefield } \\
\text { (Hermes) addresses Leto and says that he does not } \\
\text { want to fight a bride of Zeus } \\
24.024 \text {...The other Immortals urge Argeiphontes }\end{array}$ & $\begin{array}{l}\text { - } 01.038 \text {...The Immortals sent Hermes to warn } \\
\text { Aegisthus (Aigisthos) not to kill Agamemnon but } \\
\text { he did it anyway } \\
01.042 \text {...Hermes could not persuade Aegisthus } \\
\text { (Aigisthos) to spare the life of Agamemnon and } \\
\text { now must face retribution from Agamemnon's son, } \\
\text { Orestes } \\
01.084 \text {...Athene (Athena) suggests to Zeus that } \\
\text { Hermes, slayer of Argos, be sent to the island of } \\
\text { Ogygia to tell the nymph, Kalypso (Calypso), that } \\
\text { Odysseus must be allowed to proceed on his } \\
\text { homeward journey } \\
\text { - } 05.028 \text {...Zeus tells Hermes to proceed to the } \\
\text { island of Ogygia to inform the nymph, Kalypso } \\
\text { (Calypso), that Odysseus must be allowed to } \\
\text { proceed on his homeward journey } \\
05.043 \text {...Argeiphontes (Hermes) heard Zeus' } \\
\text { command and prepared to leave Mount Olympos } \\
\text { (Olympus) } \\
\text { - } 05.049 \text {...Argeiphontes (Hermes), with sandals } \\
\text { and wand, flew across the waves towards the island } \\
\text { of Ogygia } \\
05.054 \text {...Hermes flew across the wave-tops in } \\
\text { the form of a bird until he reached the island of } \\
\text { Ogygia } \\
05.075 \text {...Argeiphontes (Hermes) stands before } \\
\text { the cavern of Kalypso (Calypso) and admires the } \\
\text { natural beauty of her home } \\
05.081 \text {...Hermes did not find Odysseus in the } \\
\text { cavern with Kalypso (Calypso) because he was on }\end{array}$ \\
\hline
\end{tabular}


(Hermes) to steal the body of Hektor (Hector) so that Akhilleus (Achilles) cannot defile it

- 24.109 ...Zeus tells Thetis that the other Immortals keep urging Argeiphontes (Hermes) to steal the body of Hektor (Hector) so that her son, Akhilleus (Achilles), cannot defile it

- 24.153 ...Zeus tells Iris to go to Priam so that he can ransom the body of Hektor (Hector) from Akhilleus (Achilles); Zeus says he will send Argeiphontes (Hermes) to guide Priam

- 24.182 ...Iris tells Priam that Argeiphontes (Hermes) will safely guide him to recover the body of his son, Hektor (Hector), from Akhilleus (Achilles)

- $\quad 24.333$...Zeus took pity on Priam and sent his beloved son, Hermes, to guide the old man safely to the camp of the Akhaians (Achaeans)

- 24.339 ...Argeiphontes (Hermes) obeys Zeus and goes to Priam so that he might ransom the body of his dead son, Hektor (Hector), from Akhilleus (Achilles)

- 24.345 ...Taking his staff which wakens or mystifies mortals, Argeiphontes (Hermes) descended Mount Olympos (Olympus) towards Troy; he assumed the guise of a young nobleman and waited for Priam

- 24.352 ...Priam' herald sees the disguised Hermes waiting for them on the road

- 24.360 ...The disguised Hermes speaks kindly to Priam and asks where he is going

- 24.378 ...Argeiphontes (Hermes) confirms Priam's suspicions that a god is helping him

- 24.389 ...The disguised Argeiphontes (Hermes) deceives Priam by telling him that he is a henchman of Akhilleus (Achilles)

- 24.410 ...The disguised Argeiphontes (Hermes) assures Priam that the body of his dead son, Hektor (Hector), has not been dishonored

- 24.432 ...The disguised Argeiphontes (Hermes) refuses to accept gifts from Priam

- 24.440 ...Hermes took the reins of the wagon and steered Priam towards the Akhaian (Achaean) camp

- 24.445 ...Argeiphontes (Hermes) put a spell of sleep on the sentries around the Akhaian (Achaean) camp so that he and Priam could enter unchallenged

- 24.457 ...Hermes opens the gates to allow Priam to see Akhilleus (Achilles)

- 24.460 ....Hermes reveals his true identity to Priam and advises him on how to supplicate Akhilleus (Achilles) for the return of the body of Hektor (Hector)

- 24.468 ...Leaving Priam at the camp of Akhilleus (Achilles), Hermes returns to Mount Olympos (Olympus)

- 24.679 ...Hermes ponders as to how to help Priam safely return to Troy the beach crying for his home

- $\quad 05.085$...Hermes is questioned by Kalypso (Calypso) as to why he has come to her island

- $\quad 05.087$...Kalypso (Calypso) refers to Hermes as 'Hermes of the Gold Staff' because his wand can induce awareness or sleep in mortals

- $\quad 05.094$...Hermes ate and drank with Kalypso (Calypso) and then told her of Zeus' message and how she must release Odysseus so he can return to his home

- $\quad 05.145$...Argeiphontes (Hermes) warns Kalypso (Calypso) that she should obey Zeus or else face his wrath

- $\quad 05.148$...Argeiphontes (Hermes) leaves Kalypso (Calypso) and her island

- $\quad 05.195$...Kalypso (Calypso) leads Odysseus back to her cavern and seats him in the same spot where Hermes had been seated

- $\quad 07.137$...While Odysseus was with the Phaiakians (Phaeacians), he observed their custom of always pouring the last libation of the day to Argeiphontes (Hermes)

- $\quad 08.323$...At the request of Hephaistos (Hephaestus), Poseidon, Hermes and Apollon came to see Ares and Aphrodite trapped in Hephaistos' bed

- $\quad 08.334$...Apollon addresses Hermes and asks if he would suffer the bonds of Hephaistos (Hephaestus) if he could share the bed of Aphrodite

- $\quad 08.338$...Argeiphontes (Hermes) tells Apollon that he would suffer three times the humiliation of Ares if he could share the bed of Aphrodite

- $\quad 10.277$...As Odysseus was walking to the palace of Kirke (Circe), he encountered Hermes in the guise of a young man

- $\quad 10.281 \ldots$ Hermes tells Odysseus that Kirke (Circe) has turned his companions into pigs

- $\quad 10.302$...Argeiphontes (Hermes) gives Odysseus a plant that will serve as an antidote to the poison that Kirke (Circe) is sure to offer him when he enters her palace

- $\quad 10.307$...After advising Odysseus of the dangers of meeting Kirke (Circe), Hermes leaves in the direction of Mount Olympos (Olympus)

- $\quad 10.330 \ldots$ Kirke (Circe) is amazed that her drugs will not work on Odysseus and correctly assumes that he is the one Argeiphontes (Hermes) has told her to expect

- $\quad 11.626$...At the entrance to the Underworld, Odysseus encounters the ghost of Herakles (Heracles) which tells Odysseus of the time he brought Kerberos (Cerberus) into the light of day with the help of Hermes

- $\quad 12.390$...Odysseus says that Kalypso (Calypso) had been told by Hermes that his crew would be punished for eating the oxen of Helios 
- 24.683 ...Hermes returns to the camp of Akhilleus (Achilles) and tells Priam to hurry back to Troy while he is still unharmed

- $\quad 24.690$...Hermes drove the wagon for Priam and his herald so they could secretly leave the Akhaian (Achaian) camp

- 24.694 ...After escorting Priam and his herald to the river Xanthos (Xanthus), Hermes returns to Mount Olympos (Olympus)
- $\quad 14.435$...The swineherd, Eumaios (Eumaeus), puts food aside as an offering to the nymphs and to Hermes, son of Maia

- $\quad 15.319$...At the home of the swineherd, Eumaios (Eumaeus), the disguised Odysseus swears an oath by Hermes that he will go among the suitors

- $\quad 16.471$...The swineherd, Eumaios (Eumaeus), tells Telemakhos (Telemachus) that he was on the Hill of Hermes, above the city, when he saw a ship of evil looking men come into the harbor

- $\quad 19.396$...Odysseus' grandfather, Autolykos (Autolycus), was a master of theft and the art of the oath which had been gifts from the wily god, Hermes

- $\quad 24.001$...Hermes of Kyllene (Cyllene) summoned the souls of the dead suitors

- $\quad 24.009$...Hermes led the souls of the dead suitors past the stream of Okeanos (Oceanus), the White Rock, the gates of Helios and the country of dreams

- $\quad 24.099$...As Agamemnon and Akhilleus (Achilles) are speaking to one other in the Underworld, the courier Argeiphontes (Hermes) approaches with the souls of the dead suitors

\section{DATA ANALYSIS}

In order to understand the role of god Hermes in the "Olympian-Style of Decision Making" process we have broadened the sample of sources and we have collected twenty-two (22) ancient Greek works (see Table 1). The analysis of the 22 works allowed us to identify the most discussed attributes and activities of god Hermes. Such an approach allowed us to evaluate the knowledge of Ancient Greeks and their perceptions on the value of information and knowledge management to productive decision-making in a top level.

\section{THE CASES STUDIES}

We have analyzed twenty-two (22) ancient Greek works, in order to categorize Hermes attributes and activities. The study of these works resulted the identification of 28 references that have been categorized into five (5) attributes and activities, as presented in Table 2 .

In eleven (11) works god Hermes is discussed as an "agent" (herald and messenger). In six (6) works god Hermes is discussed as a "deliverer". In six (6) works god Hermes is discussed as a "leader". In three (3) works god Hermes is discussed as an "enforcer". And in only two (2) works god Hermes is discussed as a "merchant". This preliminary analysis indicates the god Hermes was not the god of commerce but the god of informatics. Another interpretation (based on the internationalization of ancient Greek commerce) could be that effective and efficient information and knowledge management are prerequisites for productive leadership. 
Table 2

The Summary of the Findings from the Study of the 22 Ancient Greek Works

\begin{tabular}{|c|c|c|}
\hline Personality traits & Description & References \\
\hline \multirow[t]{11}{*}{$\begin{array}{l}\text { A. Agent (herald } \\
\text { and messenger) }\end{array}$} & $\begin{array}{l}\text { "Zeus who masses the clouds made answer ... turned to his dear son } \\
\text { Hermes: 'Hermes, you are always our messenger." }\end{array}$ & Odyssey 5.4 \\
\hline & $\begin{array}{l}\text { "Glorious (Kydimos) Hermes, the herald of the deathless gods (Kerux } \\
\text { Athanaton)." }\end{array}$ & Theogony 938 \\
\hline & "Hermes, the herald of the gods." & $\begin{array}{l}\text { Hesiod The Astronomy } \\
\text { Frag } 1 \text { (from Scholiast } \\
\text { on Pindar's Nemean } \\
2.16 \text { ) }\end{array}$ \\
\hline & "Zeus made Hermes his personal herald." & Apollodorus 3.115 \\
\hline & $\begin{array}{l}\text { "Hermes ... messenger of Zeus ... Celestial messenger of various skill, } \\
\text { whose powerful arts could watchful Argos kill. With winged feet 'tis thine } \\
\text { through air to course." }\end{array}$ & $\begin{array}{l}\text { Orphic Hymn } 28 \text { to } \\
\text { Hermes }\end{array}$ \\
\hline & $\begin{array}{l}\text { "To Hermes ... are attached traditions from the poems of Homer: that } \\
\text { Hermes is the minister of Zeus." }\end{array}$ & Pausanias 8.32.4 \\
\hline & $\begin{array}{l}\text { "I [Hermes] am he who bears his father's mandates through the sky. My } \\
\text { father's Juppiter [Zeus] himself." }\end{array}$ & Metamorphoses 2.708 \\
\hline & $\begin{array}{l}\text { "Jove [Zeus] called his son aside ... 'Mercurius [Hermes]', he said, 'Trusty } \\
\text { executant of my commands, make haste, glide swiftly on your course." }\end{array}$ & Metamorphoses 2.836 \\
\hline & $\begin{array}{l}\text { "Here once came Juppiter [Zeus] ... and with his father herald Atlantiades } \\
\text { [Hermes]." }\end{array}$ & Metamorphoses 8.618 \\
\hline & $\begin{array}{l}\text { "The winged Arcadian [Hermes] is the messenger of supreme Jove [Zeus]; } \\
\text { Juno [Hera] hath power over the rain-bringing Thaumantian [Iris the } \\
\text { rainbow]." }\end{array}$ & Silvae 3.3 .80 \\
\hline & $\begin{array}{l}\text { "Father Zeus sent his quick messenger Maia's son [Hermes] on outspread } \\
\text { wings." }\end{array}$ & Dionysiaca 3.373 \\
\hline \multirow[t]{3}{*}{ B. Enforcer } & $\begin{array}{l}\text { "Men in early times sought fire from the gods, and did not know how to keep it alive. } \\
\text { Later Prometheus brought it to earth in a fennel-stalk, and showed men how to keep it } \\
\text { covered over with ashes. Because of this, Mercurius [Hermes], at Joveís [Zeusí] } \\
\text { command, bound him with iron spikes to a cliff on Mount Caucasus, and set an eagle } \\
\text { to eat out his heart." }\end{array}$ & Hyginus Fabulae 144 \\
\hline & $\begin{array}{l}\text { " Mercurius [Hermes], by Joveís [Zeusí] instructions, bound Ixion in the Land of the } \\
\text { Dead to a wheel [for attempting to seduce Hera], which is said to be still turning } \\
\text { there." }\end{array}$ & Hyginus Fabulae 62 \\
\hline & $\begin{array}{l}\text { "Jove [Zeus] called his son aside and, keeping dark his secret passion, 'Mercurius } \\
\text { [Hermes]', he said, 'Trusty executant of my commands, make haste, glide swiftly on } \\
\text { your usual course down to the land that sees your mother's [the Pleiad Maia's] star } \\
\text { high in the southern sky, named by its people the land of Sidon [in Phoinikia]; in the } \\
\text { distance there, grazing the mountain pastures, you will find the royal herd; drive them } \\
\text { to the sea-shore.' And presently, as Jove [Zeus] had bidden, the herd, driven from the } \\
\text { hillside, headed for the shore, where with her girls of Tyre for company the great } \\
\text { king's daughter often used to play [and amongst them Zeus assumed the form of a bull } \\
\text { in order to seduce Europa]." }\end{array}$ & Metamorphoses 2.836 \\
\hline \multirow[t]{2}{*}{ C. Merchant } & $\begin{array}{l}\text { "[Herakles] was told [by the oracle at Delphoi] that the cure for the disease [inflicted } \\
\text { upon him for the murder of Iphitos] consisted of his being sold into bondage for three } \\
\text { years ... When the oracle had been given, Hermes put Herakles up for sale. Omphale } \\
\text { [queen of Lydia], daughter of Iardanos, bought him." }\end{array}$ & Apollodorus 2.131 \\
\hline & $\begin{array}{l}\text { " Hercules because of this offence [the murder of his children in madness or the theft } \\
\text { of Apollon's Delphic tripod] was given in servitude to Queen Omphale by Mercurius } \\
\text { [Hermes]." }\end{array}$ & Hyginus Fabulae 32 \\
\hline \multirow[t]{2}{*}{ D. Leader } & $\begin{array}{l}\text { "At Zeus' command, Athena and Hermes purified the daughter [of Danaus who } \\
\text { murdered their husbands] ... and he [their father] married off his daughters to the } \\
\text { victors of a gymnastic contest." }\end{array}$ & "Apollodorus 2.22 \\
\hline & $\begin{array}{l}\text { "Stesichorus in his Funeral Games of Pelias says that Hermes gave the Dioskouri } \\
\text { [who were competing in the chariot-race] Phlogeus and Harpagos, swift foals of } \\
\text { Podarge." }\end{array}$ & $\begin{array}{l}\text { Greek Lyric III } \\
\text { Stesichorus Frag } 178 \\
\text { (from Etymologicum } \\
\text { Magnum) }\end{array}$ \\
\hline
\end{tabular}




\begin{tabular}{|c|c|c|}
\hline & $\begin{array}{l}\text { "The [Homeric] epic called 'The Cypria' which is current is eleven books. Its contents } \\
\text { are as follows. Zeus plans with Themis to bring about the Trojan war. Eris (Strife) } \\
\text { arrives while the gods are feasting at the marriage of Peleus and starts a dispute } \\
\text { between Hera, Athena, and Aphrodite as to which of them is fairest. The three are led } \\
\text { by Hermes at the command of Zeus to Alexandros [Paris] on Mount Ida for his } \\
\text { decision, and Alexandros, lured by his promised marriage with Helene, decides in } \\
\text { favour of Aphrodite." }\end{array}$ & $\begin{array}{l}\text { The Cypria Frag } 1 \text { (as } \\
\text { summarized in Proclus, } \\
\text { Cherstomathia 1) }\end{array}$ \\
\hline & $\begin{array}{l}\text { "Eris tossed an apple to Hera, Athena, and Aphrodite, in recognition of their beauty, } \\
\text { and Zeus bade Hermes escort them to Alexandros on Ida to be judged by him." }\end{array}$ & Apollodorus E3.2 \\
\hline & $\begin{array}{l}\text { "Some say that Helene [when she eloped with Paris], in accordance with the will of } \\
\text { Zeus, was kidnapped by Hermes and taken to Aigyptos, where she was put in the } \\
\text { safekeeping of the Aigyptian king Proteus, and that Alexandros proceeded to Troy } \\
\text { with an image of Helene made from clouds." }\end{array}$ & Apollodorus E3.5 \\
\hline & $\begin{array}{l}\text { "[Depicted on the throne of the Amyklaian:] Hermes is bringing the goddesses to } \\
\text { Alexander to be judged." }\end{array}$ & Pausanias 3.18 .12 \\
\hline \multirow[t]{6}{*}{$\begin{array}{l}\text { E. Deliverer of } \\
\text { Infants Into Foster- } \\
\text { Care }\end{array}$} & $\begin{array}{l}\text { "Kallisto ... was loved by Zeus and mated with him. When Hera detected the intrigue } \\
\text { she turned Kallisto into a bear, and Artemis to please Hera shot the bear. Zeus sent } \\
\text { Hermes with orders to save the child [Arkas] that Kallisto bore in her womb." }\end{array}$ & "Pausanias 8.3.6 \\
\hline & $\begin{array}{l}\text { "Zeus loosed the stitches [from his thigh] and gave birth to Dionysos, whom he } \\
\text { entrusted to Hermes. Hermes took him to Ino and Athamas, and persuaded to bring } \\
\text { him up as a girl ... [After Hera drew the pair mad but] Zeus, escaped Hera's anger by } \\
\text { changing Dionysos into a baby goat. Hermes took him to the Nymphai of Asian Nysa, } \\
\text { whom Zeus in later times placed among the stars and named the Hyades." }\end{array}$ & Apollodorus 3.28-29 \\
\hline & $\begin{array}{l}\text { "[Depicted on the throne of the Amyklaian:] Hermes is bearing the infant Dionysus to } \\
\text { heaven." }\end{array}$ & Pausanias 3.18 .11 \\
\hline & $\begin{array}{l}\text { "It was Makris [daughter of Aristaios], who in Abantian Euboia, took the infant } \\
\text { Dionysos to her bosom and moistened his parched lips with honey, when Hermes had } \\
\text { rescued him from the flames and brought him to her." }\end{array}$ & Argonautica 4.1128 \\
\hline & $\begin{array}{l}\text { "Zeus taking up the child [Dionysos from the body of its mother Semele], handed it } \\
\text { over to Hermes, and ordered him to take it to the cave in Nysa, which lay between } \\
\text { Phoinikia [modern day Lebanon] and the Neilos [River Nile in Egypt], where he } \\
\text { should deliver it to the Nymphai that they should rear it and with great solicitude } \\
\text { bestow upon it the best of care." }\end{array}$ & Diodorus Siculus 4.2.3 \\
\hline & $\begin{array}{l}\text { "Semele [consumed in the fire of Zeus lightning] saw her fiery end, and perished } \\
\text { rejoicing in a childbearing death [the baby Dionysos] ... So the babe half-grown, and } \\
\text { his limbs washed with heavenly fire, was carried by Hermes to his father for the lying- } \\
\text { in [placed within the thigh of the god]." }\end{array}$ & Dionysiaca 8.402 \\
\hline \multicolumn{3}{|l|}{ Sources: } \\
\hline \multicolumn{3}{|c|}{ Homer, The Iliad - Greek Epic C9th-8th BC } \\
\hline \multicolumn{3}{|c|}{ Homer, The Odyssey - Greek Epic C9th-8th BC } \\
\hline \multicolumn{3}{|c|}{ Hesiod, Catalogues of Women - Greek Epic C8th-7th BC } \\
\hline \multicolumn{3}{|c|}{ Homerica, The Cypria - Greek Epic BC } \\
\hline \multicolumn{3}{|c|}{ Pindar, Odes - Greek Lyric C5th BC } \\
\hline \multicolumn{3}{|c|}{ Greek Lyric III, Stesichorus - Greek Lyric C7th-6th BC } \\
\hline \multicolumn{3}{|c|}{ Greek Lyric IV Corinna, Fragments - Greek Lyric C5th BC } \\
\hline \multicolumn{3}{|c|}{ The Orphic Hymns - Greek Hymns C? BC } \\
\hline \multicolumn{3}{|c|}{ Euripides, Helen-Greek Tragedy C5th BC } \\
\hline \multicolumn{3}{|c|}{ Aesop, Fables - Greek Fables C6th BC } \\
\hline \multicolumn{3}{|c|}{ Apollodorus, The Library - Greek Mythography C2nd BC } \\
\hline \multicolumn{3}{|c|}{ Apollonius Rhodius, The Argonautica - Greek Epic C3rd BC } \\
\hline \multicolumn{3}{|c|}{ Pausanias, Guide to Greece - Greek Geography C2nd AD } \\
\hline \multicolumn{3}{|c|}{ Diodorus Siculus, The Library of History - Greek History C1st BC } \\
\hline \multicolumn{3}{|c|}{ Hyginus, Fabulae - Latin Mythography C2nd AD } \\
\hline \multicolumn{3}{|c|}{ Ovid, Metamorphoses - Latin Epic C1st BC - C1st AD } \\
\hline \multicolumn{3}{|c|}{ Ovid, Fasti - Latin Epic C1st BC - Clst AD } \\
\hline \multicolumn{3}{|c|}{ Statius, Silvae - Latin Epic C1st AD } \\
\hline \multicolumn{3}{|c|}{ Apuleius, The Golden Ass - Latin Novel C2nd AD } \\
\hline \multicolumn{3}{|c|}{ Servius, On Virgil's Aeneid - Latin Scholarship C4th AD } \\
\hline \multicolumn{3}{|c|}{ Colluthus, The Rape of Helen - Greek Epic C5th-6th AD } \\
\hline \multicolumn{3}{|c|}{ Nonnos, Dionysiaca - Greek Epic C5th AD } \\
\hline
\end{tabular}


The above analysis of god Hermes' attributes and activities indicates that he was the most sympathetic, the most baffling, the most confusing, the most complex, and therefore the most Greek of all the Olympian gods. The following archetypal analysis it is a quite unknown field for the scholars from Economics and Business Administration. This gap raises issues about the need not only to deepen our historical knowledge but also to empower our knowledge by analyzing archetype symbols, as sources of hidden knowledge. The knowledge of the cultural roots of Economics and Management Science will promote our understanding of this vital topic and will deepen our thinking about its importance and usefulness, both as a practical and theoretical ergon/engagement discipline. In terms of this research challenge, the following review of Hesiod's and Homer's works will allow us to understand (in a significant level) the hidden knowledge of Ancient Greeks on decision-making theories and management science.

We have interpreted the works both holistically and coding. Through holistic analysis we didn't attempt to break the evidence into parts, but rather to draw conclusions based on the text as a whole. Flower and Hayes (1981), for example, make inferences from entire sections of their students' protocols, rather than searching through the transcripts to look for isolatable characteristics.

However, coding approach allowed us to identify and/or categorize specific observable actions or characteristics. These observable actions then become the key variables in the study. Sharan Merriam (1988) suggests seven analytic frameworks for the organization and presentation of data: a. the role of participants, b.the network analysis of formal and informal exchanges among groups., c. historical, d. thematical, e. resources, f. ritual and symbolism, g. critical incidents that challenge or reinforce fundamental beliefs, practices, and values.

There are two purposes of these frameworks: to look for patterns among the data and to look for patterns that give meaning to the case study approach.

As stated above, while most researchers begin their case studies expecting to look for particular observable characteristics, it is not unusual for key variables to emerge during data collection. Typical variables coded in case studies of writers include pauses writers make in the production of a text, the use of specific linguistic units (such as nouns or verbs), and writing processes (planning, drafting, revising, and editing). In the Berkenkotter, Huckin, and Ackerman (1988) study, for example, researchers coded the participant's texts for use of connectives, discourse demonstratives, average sentence length, off-register words, use of the first person pronoun, and the ratio of definite articles to indefinite articles.

Since coding is inherently subjective, more than one coder is usually employed. In the Berkenkotter, Huckin, and Ackerman (1988) study, for example, three rhetoricians were employed to code the participant's texts for offregister phrases. The researchers established the agreement among the coders before concluding that the participant used fewer off-register words as the graduate program progressed.

\section{COMMENTARY OF THE FINDINGS FOR THE OLYMPIAN STYLE OF DECISION MAKING - A COMBINATION OF RATIONAL AND POLITICAL APPROACH OF GROUP DECISION-MAKING?}

\subsection{The Rational Approach}

Assumes that complete information regarding the decision to be made is available and one correct conception of a problem, or decision to be made can be determined. This approach further assumes that the decision-makers consistently assess the advantages and disadvantages of any alternatives with goals and objectives in mind. They then evaluate the consequences of selecting or not selecting each alternative. The alternative that provides the maximum utility (i.e., the optimal choice) will be selected. The rational approach is the baseline against which other models are compared according to Allison (1971) Cheshire and Feroz (1989) Lyles and Thomas (1988).

The most salient advantage of the rational approach is that it utilizes a logical, sequential approach. Decisions are made deductively by determining the goals or objectives to be obtained, evaluating the potential alternatives based on the information at hand and choosing the optimal alternative. In other words, the approach is simple and intuitive in nature. 
The rational approach does possess a salient disadvantage. The model assumes that there are no intrinsic biases to the decision-making process (Lyles and Thomas, 1988). This optimism may not be totally realistic, since individuals involved in the process bring their own perceptions and mental models into such a situation. Therefore, it seems that intrinsic biases are inevitable and something that should be addressed.

\subsection{The Political Approach}

The other decision-making approach considers the preconceived notions that decision-makers bring to the table in the decision process. This model is the political approach. In this approach, the individuals involved do not accomplish the decision task through rational choice in regard to objectives. The decision makers are motivated by and act on their own needs and perceptions (such as Zeus). This process involves a cycle of bargaining among the decision makers in order for each one to try to get his or her perspective to be the one of choice. More specifically, this process involves each decision-maker trying to sway powerful people within the situation to adopt his or her viewpoint and influence the remaining decision-makers, according to Allison (1971), Cheshire and Feroz (1989), Lyles and Thomas (1988), Schneider et al. (1993).

Furthermore, the political approach does not involve making full information available or a focus on the optimal viewpoint like that of the rational model (Lyles and Thomas, 1988). Full information is highly unlikely, since the political approach model operates based upon negotiation that is often influenced by power and favors. In fact, information is often withheld in order to better maneuver a given perspective. Since information is often withheld and subsequently incomplete, the optimal viewpoint is not a key aspect of this approach.

The advantages of the political approach remains that it provides a representation of the subjective manner in which the real world often operates, and it can minimize conflict. Individuals will always have their personal biases and agendas that influence their behavior. By identifying or acknowledging this fact in the decision-making process, potential problems and conflict can be foreseen and minimized. The swaying of powerful people to support a particular viewpoint also minimizes conflict. Once the powerful people support this perspective, other group members usually fall in line behind them.

While the political approach has the advantage of emulating the way the real world operates (i.e., a cycle of bargaining related to personal agendas), this fact is also a disadvantage, because the best solution or decision may not be selected. Furthermore, the nature of bargaining and maneuvering (e.g., withholding information and social pressure) can produce effects that are long lasting and detrimental. Once they discover it, the individuals involved in the decision may not appreciate the duplicity inherent in the process.

\section{PROPOSITION}

Many historians and archaeologists fail to recognize that the Delphic Oracle was the first organized "DataBank" and the "Central Intelligence Service" of a worldwide Network and established a "Systematic Web Process" for gathering information from all parts of then known world. The important aspect of this institution was its originality and innovative status: its successes made it well known all over the world up to our times.

The Delphic Oracle System (D.O.S.), though based on religious and cult functions, in fact, it was a wellorganized technocratic agency aiming to collect information and to use it for forecasts and consulting. It is important to note that it was used in nearly all cases of public issues such as war preparations, sanctions against other city states, conflicts or clashes etc.

Today, in the age of informatics and widespread use of Internet services everybody realizes the importance of information and communication services. What we can recognize through the works of modern historians such as Parke and Wormell (1956), Nilsson (1972), Fontenrose (1975), Miller (1941) that ancient Greeks believed and accepted the following "equations": 
Information and Knowledge $\approx$ Intellectual Power or

1

Information and Knowledge $\approx$ Wise Decisions

and therefore: Intellectual Power $\approx$ Wise Decision

If we introduce another "variable" in the above system of "equations" [1] to [3], that is:

(Perfect) Information $\approx$ Accurate Forecasts

and: Accurate Forecasts $\rightarrow$ Wise Decisions
2

3

4

5

\section{DISCUSSION}

Organizational performance is largely dependent upon the decision-making processes that a particular organization uses. In every organization, decisions have to be made on a daily basis. These decisions range from small to large-scale in scope both in terms of the resources involved in making them and the impact that the decisions can have.

Group decision-making is the process of arriving at a judgment based upon the feedback of multiple individuals. Such decision-making is a key component to the functioning of an organization, because organizational performance involves more than just individual action. Due to the importance of the group decision-making process, decision-making models can be used to establish a systematic means of developing effective group decision-making.

The knowledge of the cultural roots of Economics and Management Science will promote our understanding of this vital topic and will deepen our thinking about its importance and usefulness, both as a practical and theoretical ergon/engagement discipline. In terms of this research challenge, the processing of Hesiod's and Homer's works allowed us to understand (in a significant level) the hidden knowledge of Ancient Greeks on decision-making theories and management science.

It is true that the Delphic Oracle as the first "Data-Bank" of a World Wide Network, establishing a systematic Web Process for gathering and evaluating information and expert opinions to be used as inputs for forecasts and rational decision-making, had some disadvantages. This expected due to the lack of adequate resources and poor technology support.

Many historians and archaeologists fail to recognize that the Delphic Oracle was the first organized "DataBank" and the "Central Intelligence Service" of a worldwide Network and established a "Systematic Web Process" for gathering information from all parts of then known world. The important aspect of this institution was its originality and innovative status: its successes made it well known all over the world up to our times.

The Delphic Oracle System (D.O.S.), though based on religious and cult functions, in fact, it was a wellorganized technocratic agency aiming to collect information and to use it for forecasts and consulting. It is important to note that it was used in nearly all cases of public issues such as war preparations, sanctions against other city states, conflicts or clashes etc.

Today, in the age of informatics and widespread use of Internet services everybody realizes the importance of information and communication services.

\subsection{Implications}

Decision-making in groups has also taken a shot in the arm from modern technology. In the twentieth century. Group decision-making is nothing new. Ancient Greece's attempt at democracy is hardly one that can be forgotten, nor the uncountable number of political councils and courts that have served for group decision-making throughout the history of Mankind. However the methods of group decision-making have evolved in this century from the establishing of rules of conduct in debates to modern use of technology. The work at N.T.L. labs mentioned earlier has led to a number of Group methods. Delphi, for example, is a method where each participant can remain anonymous, usually filling in a questionnaire or by an interview process with a facilitator. This procedure avoids 
Table 3

The Modified Generalized Model on Decision-Making in Groups for Private and Public Organizations

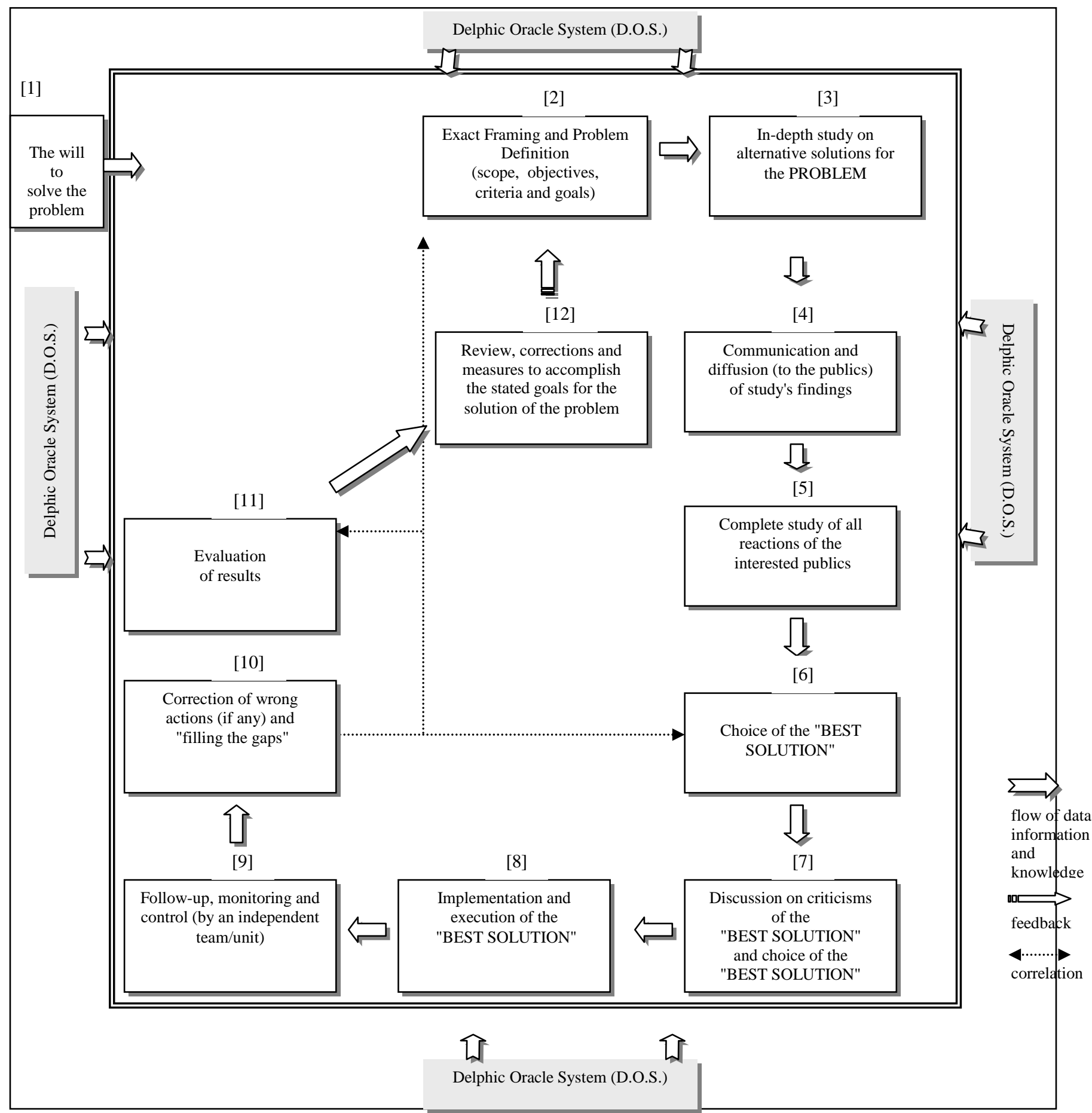


dominance by strong personalities. in a direct group meeting process. All the judgments are compiled and reviewed anonymously by an appointed person, and the results sent to each group member for review. Several rounds of this process may be made before consensus is arrived at. Often the criteria are limited in number to make the questionnaire manageable, and frequently they are set by some prior procedure. Throughout, anonymity is maintained. In another technique, the group may assemble in one place and utilize modern technology to vote in groups. For example, remotes similar to those used for TV may be given each member (gathered in a room) and a coordinator will guide the group through the process using software which interprets each remote input, and which automatically will tabulate the results for immediate feedback. Anonymity may be removed, but the advantage is that the decision with its criteria and weights can be negotiated and built in a facilitated and rapid process. The facilitator, a consultant or specialist in the area, often analyzes the results of the decision. Areas such as health care in the US and Canada, decisions on energy producing facilities by the Finnish Government, and the likelihood of ground contamination from nuclear waste product casings have used such group facilitation methods. Today it is not uncommon for a government or large business organization to resort to group decision-making methodologies. New on the scene is another method that is slowly gaining ground but has yet to evolve to a point where the group decision process is truly effective. This is the area of remote and often asynchronous decision-making. Here each participant may build his/her own model. The models are combined by a facilitator, or possibly sent to all other members of the group by all other members of the group. Lotus Notes is an early attempt at this type of decision-making technology. By accounts it seems that the process results in better decisions (higher consensus) but is often slower than a group facilitated meeting. However, it is less expensive in terms of time and travel for many members. The method, however, can now be more sophisticated. The Lotus Notes approach has no concept of weights and criteria setting, and is more a 'round robin' method. With TEC's TESS the process can be set into a more sophisticated decision-making tool, where each may create their own model, anonymously or otherwise, and the models combined in the decision-making process under a well-illustrated and documented procedure.

Software products are group assisted decision-making tools where people sit at a set of PC's (locally or remotely) and place their votes, notes and decision-making commentaries largely from the keyboard, often through a facilitated process.

Videoconferencing is another regime that has become popular (and possible) over the past few years. As PC's developed sufficiently fast modems in the early 1990's, and software has developed, so to has the ability for people in almost any part of a distributed network to form groups and reach consensus without the need for travel. For many, this new technology holds promise of lower decision-making costs, though for some decisions there is always likely to be the need to meet and look the other in the eye before a final decision is made! For others it is a wrap-up process from more fundamental or broader agreements made in face-to-face discussions and meetings.

This study seeks to make a contribution by drawing insights from Greek mythology to suggest a generalized model for group decision-making for enhancing leadership in all socio-economic areas.

The cultural roots of Economics, Management Science, Informatics and Marketing are related to its genesis, mythology, and prehistory and of course, to its proto-foundations as a scientific discipline. The World Book Encyclopedia says: "we study mythology because it is the religion of a primitive people. And it is their science and literature as well. It is their religion because it tells what the gods do and what the people should do to please the gods. It is their science because it explains natural events by making up supernatural causes for them." (1955 edition, Vol.11, p.5375). Unfortunately, economists and management scientists know very little or nothing about the cultural roots of our discipline, despite the fact that Economics is indeed the most vital activity of all other human activities. The analysis of archetypes it seems to be a quite unknown field for the majority of the academics from the different fields of Economics and Business Administration. This gap raises issues about the need not only to deepen our historical knowledge but also to empower our knowledge by analyzing archetype symbols, as sources of hidden knowledge. The knowledge of the cultural roots of Economics and Management Science will promote our understanding of this vital topic and will deepen our thinking about its importance and usefulness, both as a practical and theoretical ergon/engagement discipline. 
A crucial part of our proposition [based on the concept of "Olympian Style of Management", introduced by Theofanides (1999)] is the term of organizational system design, which means decisions about formal structures, processes, roles and relationships (Walter and Nadler 1994). More specifically, the characteristics, which will be affected by a change in the organization's mission and strategy will encompass the organizational form (functional, divisional, matrix), the grouping of business units (function, product/service, target market), hierarchical levels (many, few), planning and control systems, job specialization, training and education programs, degree of centralization, delegation and participation (Volberda 1996). This indicates the crucial need for synthesizing a mathematically designed organizational system in order decision making for grand strategies/decisions to meet success.

\subsection{Research Directions}

Socrates may very likely be the first person who attempted to teach leadership skills. The subject is discussed in both Plato's Dialogues and Xenophon's Memorabilia While Plato the academic and Xenophon the practitioner began the tradition of thinking about leadership, it was Scotland's oldest University, St Andrews that instituted lecture series in leadership in the 1930s, which may have been one of the earliest modern attempts to study and/or teach leadership skills in an academic environment. Since then, social scientists have spent considerable time and effort studying leadership. Recent years have seen a dramatic increase in the level of interest in the subject of leadership. Witness the proliferation of books on leadership, articles in business publications about leadership and institutions offering leadership training. A recent Internet search using the word "leadership" netted over 1.2 million "hits".

Further conceptualized research, can be undertaken, as new theories of business education and leadership is needed. Synergistic leadership theory is not enough. There is a highest research priority to examine leadership efficiency and how education in fields of Economics, Business Administration and Informatics can contribute in such a strategic direction. There is a need to examine a series of external forces, characteristics of the organization, attitudes and beliefs, in order to reengineer the philosophy of education in many business schools.

Based on Hansen et al. (1988) findings, there is a major risk of the isolationism in fields, such as marketing, because of the wrong perception the many marketing academics and marketing educators practitioners for leadership development. Such attitudes seem to have direct impact to the low interaction of many marketing graduates with other key functions of an organization. Consequently, in order to avoid decision sciences contribution shrunk, new conceptualized approaches for business education philosophy are needed in order these threats to be dealt in time. So, the development of systemic thought seems to be the major challenge in business and economic education both for academics and practitioners, in the next years.

\section{CONCLUSION}

From a contemporary view, the figure of Hermes, according to a plethora of ancient Greek works, stands as an archetype of transformation through reconciliation of the opposites. If we are inclined to this view, we should rejoice over the renewed interest in Hermes and his timeless gnosis.

\section{REFERENCES}

1. Allison, G.T. (1971) Essence of decision: Explaining the Cuban missile crisis. Little, Brown and Company, Boston.

2. Berkenkotter, C., Huckin T, and Ackerman, J. (1988) Conventions, Conversations and the Writer: Case Study of a Student in a Rhetoric Ph.D. Program. Research in the Teaching of English vol.22, 9-44.

3. Bogdanowicz, M.S. and Bailey, E.K. (2002) The value of knowledge and the values of the new knowledge worker: Generation X in the new economy. Journal of European Industrial Training vol.26(2/3/4), 125-129.

4. $\quad$ Bolen, J.S. (1984) Goddesses in Every Woman. Harper and Row, New York.

5. Bolen, J.S. (1989) Gods in Every Man. Harper and Row, New York.

6. Boyd, A. (2004) Multi-channel information seeking: a fuzzy conceptual model. Aslib Proceedings: New Information Perspectives vol.56(2), 81-88. 
7. Burstein, F. and Linger, H. (2003) Supporting post-Fordish work practices: a knowledge management framework for supporting knowledge work. Information Technology and People vol.16(3), 289-305.

8. Cheshire, J.D. and Feroz, E.H. (1989) Allison's models and the FASB statements no's 2, 5, 13 and 19. Journal of Business Finance and Accounting vol.16(1), 119-130.

9. Cleveland, H. (1982) Information as a resource. The Futurist December, 34-39.

10. Emig, J. (1971) The Composing Processes of Twelfth Graders. NTCE, Urbana.

11. Flower, L. and Hayes, J.R. (1984) Images, Plans and Prose: The Representation of Meaning in Writing. Written Communication vol.1, 120-160.

12. $\quad$ Fontenrose, J. (1975) The Delphic Oracle. University of California Press, Berkeley.

13. Hansen, S., Carlsson, Ch., and Walden, P. (1988) Marketing Education: Present Needs and Future Challenges. European Journal of Marketing vol.22(3), 48-60.

14. Lyles, M.A. and Thomas, H. (1988) Strategic problem formulation: Biases and assumptions embedded in alternative decision-making models. Journal of Management Studies vol.25(2), 131-145.

15. Merriam, S.B. (1985) The Case Study in Educational Research: A Review of Selected Literature. Journal of Educational Thought vol.19(3), 204-217.

16. Merriam, S.B. (1988) Case Study Research in Education: A Qualitative Approach. Jossey Bass, San Francisco.

17. Miller, H. (1941) The Colossus of Maroussi. Colt Press, San Francisco.

18. Nilsson, M.P. (1972) Cults, Myths, Oracles and Politics in Ancient Greece. New York.

19. Oppenheim, C., Stenson, J. and Wilson, R.M.S. (2000) Valuation of information assets in UK companies. Managing Information, 56-61.

20. Parke, H.W. and Wormell, D.E.W. (1956) The Delphic Oracle, vol. I, II. Basil Blackwell, Oxford.

21. Schneider, J.K., Shawver, M.M., and Martin, A. (1993) Applying a political model to program development. Nursing Management vol.24(10), 52-55.

22. Squier, M.M. and Snyman, R. (2004) Knowledge management in three financial organizations: a case study. Aslib Proceedings: New Information Perspectives vol.56(4), 234-242.

23. Theofanides, S. (1989) A Manual for Effective Management of Public Affairs. Papazisis, Athens.

24. Theofanides, S. (1999) The Olympian Style of Management: The First Model of Decision Making at the Top. 5th International Conference Proceedings: Integrating Technology \& Human Decisions - Global Bridges Into the 21st Century vol.1, 780 .

25. Volberda, H.W. (1996) Toward the Flexible Form: How to Remain Vital in Hypercompetitive Environments. Organizations Science vol.7(4), 359-374.

26. Wallis, J. (2003) Information-saturated yet ignorant: information mediation as social empowerment in the knowledge economy. Library Review vol.52(8), 369-372.

27. Walter, E. and Nadler, D. (1994) Diagnosis for organization design. The Guilford Press, New York. 